\title{
PROGESTERONE PRODUCTION IN SUPEROVULATED HOLSTEIN HEIFERS AND IN CROSSBRED RECIPIENT OF EMBRYO SUPPLEMENTED WITH BETACAROTENE AND TOCOPHEROL
}

\author{
Produção de progesterona em novilhas Holandesas superovuladas e receptoras de embrião \\ mestiças suplementadas com betacaroteno e tocoferol
}

\author{
José Nélio de Sousa Sales ${ }^{1}$, Lilian Mara Kirsch Dias², Celso Rodrigues Franci, \\ Alexandro Aluísio Rocha ${ }^{4}$, Guilherme Gastão Cardoso ${ }^{5}$, José Camisão de Souza ${ }^{6}$
}

\begin{abstract}
Two experiments were conducted to evaluate the effect of the intramuscular injection of betacarotene associated to tocopherol on the plasma concentration progesterone of superovulated Holstein heifers (experiment 1) and in crossbred (Bos taurus x Bos indicus) heifers submitted to fixed-time embryo transfer (FTET, experiment 2). In experiment 1, after estrus synchronization and superovulation animals were inseminated 12 and 24 hours after estrus onset and embryos flushed 7 days later. Heifers were allocated randomly to one of three treatments: Control; T800 (800 mg of betacarotene plus $500 \mathrm{mg}$ of tocopherol) and T1200 (1,200 mg of betacarotene plus $750 \mathrm{mg}$ of tocopherol). The treatments were given on the day of ear implant placement and repeated on the first day of superovulation. Blood samples were collected on D0, D5, D9, D12 and D16. In experiment 2, treatments were imposed at intravaginal device insertion (D0). The same experimental design, as in experiment 1, was used. Blood samples were collected on D17 (embryos implanted) for progesterone determination by radioimmunoassay. In experiment 1, average plasma progesterone concentrations after corpora lutea formation (D12 plus D16 means) were $13.7 \pm 1.8 \mathrm{ng} / \mathrm{ml}, 14.5 \pm 2.3 \mathrm{ng} / \mathrm{ml}$ and $10.8 \pm 2.3 \mathrm{ng} / \mathrm{ml}$ for control, T800 and T1200, respectively, and did not differ $(P=0.44)$. In experiment 2, progesterone concentrations on D17 in Control $(8.88 \pm 0.57 \mathrm{ng} / \mathrm{ml}), \mathrm{T} 800(7.48 \pm 0.64 \mathrm{ng} / \mathrm{ml})$ and T1200 $(5.90 \pm 1.33 \mathrm{ng} / \mathrm{ml})$ groups were similar $(\mathrm{P}=0.11)$. Results indicate that the supplemental betacarotene and tocopherol injections did not influence peripheral progesterone concentrations in superovulated Holstein donors and crossbreed recipients heifers.
\end{abstract}

Index terms: Vitamin, reproduction, cattle, embryo transfer.

\section{RESUMO}

Dois experimentos foram conduzidos para avaliar o efeito da injeção intramuscular de betacaroteno associada ao tocoferol, na concentração plasmática de progesterona de novilhas Holandesas superovuladas (Experimento 1) e em novilhas cruzadas (Bos taurus x Bos indicus) submetidas à transferência embrionária em tempo fixo (TETF, experimento 2). No experimento 1, após a sincronização do estro e superovulação, os animais foram inseminados entre 12 a 24 h após o início do estro e os embriões recuperados após 7 dias. As novilhas foram divididas, aleatoriamente, em 1 de 3 tratamentos: Controle (duas injeções de soro); T800 (800 mg de betacaroteno mais $500 \mathrm{mg}$ de tocoferol) e T1200 (1.200 mg de betacaroteno mais $750 \mathrm{mg}$ de tocoferol). Os tratamentos foram administrados no dia da colocação do implante de progesterona e repetido no primeiro dia da superovulação. As colheitas de sangue foram realizadas no D0, D5, D9, D12 e D16. No experimento 2, os tratamentos foram realizados no momento da inserção do dispositivo de progesterona (D0). Utilizou-se o mesmo delineamento do experimento 1. A colheita de sangue para a determinação da progesterona por radioimunoensaio foi realizada no D17 (inovulação embrionária). No experimento 1, a concentração

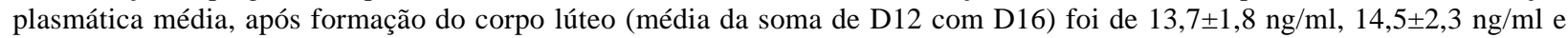
$10,8 \pm 2,3 \mathrm{ng} / \mathrm{ml}$ para os grupos Controle, T800 e T1200, respectivamente, e não diferiram $(P=0,44)$ entre os tratamentos. No experimento 2, a concentração de progesterona nas receptoras, no dia 17 , foi semelhante $(\mathrm{P}=0,11)$ entre os grupos controle $(8,88 \pm 0,57 \mathrm{ng} / \mathrm{ml}), \mathrm{T} 800(7,48 \pm 0,64 \mathrm{ng} / \mathrm{ml})$ e $\mathrm{T} 1200(5,90 \pm 1,33 \mathrm{ng} / \mathrm{ml})$. Os resultados indicaram que as injeções de suplemento com betacaroteno e tocoferol não influenciaram na concentração plasmática de progesterona em novilhas Holandesas doadoras de embriões e em novilhas cruzadas, receptoras de embrião.

Termos para indexação: Vitamina, reprodução, gado, transferência de embriões.

(Received in july 22, 2010 and approved in february 4, 2011)

\footnotetext{
1Universidade de São Paulo/USP - Departamento de Reprodução Animal/VRA - São Paulo, SP

¿Universidade de São Paulo/USP - Faculdade de Medicina Veterinária e Zootecnia/FMVZ - Departamento de Reprodução Animal/VRA - Avenida Professor Doutor Orlando Marques de Paiva - 87 - Cidade Universitária - 05508-000 - São Paulo, SP - lilikirsch@gmail.com

${ }^{3}$ Universidade de São Paulo/USP - Departamento de Fisiologia - São Paulo, SP

${ }^{4}$ Universidade Federal dos Vales do Jequitinhonha e Mucuri/UFVJM - Departamento de Ciências Básicas - Diamantina, MG

${ }^{5}$ Empresa Paraíso dos Embriões - Poços de Caldas, MG

${ }^{6}$ Universidade Federal de Lavras/UFLA - Departamento de Zootecnia/DZO - Lavras, MG
} 


\section{INTRODUCTION}

Betacarotene is a lipid soluble isoprenoid pigment and it is produced by plants and other photosynthetic organisms. This carotenoid is the natural precursor of vitamin A in feedstuff and it is converted to retinol, in the liver and used in tissues as retinal (BENDICH; OLSON, 1989). Tocopherol is a lipid soluble organic alcohol biologically active and it is responsible for most of the action of vitamin $\mathrm{E}$ in feedstuffs (BREGELIUS; TRABER, 1999; MESTRE; CALLAN, 2001). Tocopherol is an excellent natural antioxidant that protects carotenoids and other materials oxidables in feed and in the body (LAL THANKUR; SRIVASTAVA, 1996). These two vitamins are potent antioxidants (WOJCIK et al., 2010). Thus, any substance that, are present in low concentrations compared to the oxidable substrate, delays or inhibits the oxidation of this substrate efficiently (SIES; STAHL, 1995; JONHSON, 2009).

Some researchers have demonstrated that either under in vitro or in vivo conditions there is a relationship between nutrition and reproductive physiology (LEROY et al., 2008; SANTOS et al., 2008; CAMPANILE et al., 2010). The action of betacarotene on steroidogenesis is achieved through the destruction or inactivation of reactive oxygen species (ROS). Steroidogenesis releases large amounts of ROS and high betacarotene concentrations in the ovaries may protect the cells from oxidative damage (ARIKAN; RODWAY, 2000). The first evidence for the antioxidative effect of betacarotene on luteal cells, reported by Young et al. (1995) was that, the supplementation of cells in vitro culture with betacarotene reduced the links between the cholesterol side-cleavage enzyme and adrenodoxin. These results were latter confirmed by Rapoport et al (1998), whom determined a significant positive correlation between the concentrations of lutheal P450 cytochrome, betacarotene and plasma progesterone.

There are evidences for the control of steroidogenesis by ROS, especially over the superoxide radical. Phospholipase $\mathrm{C}$ may stimulate the production of superoxide radicals that inhibit ovarian progesterone synthesis in rats (BILSKA et al., 1991). Thus, betacarotene and vitamin $\mathrm{E}$ act protecting the phospholipid membrane of action of ROS. This action may explain, in part, the ability of betacarotene in maintaining progesterone synthesis in luteal cells (ATEN et al., 1992; ARIKAN; RODWAY, 2000). Moreover, betacarotene stimulates and induces the synthesis of the cholesterol side chain cleavage enzyme, increases cAMP concentrations and activates protein kinase C-dependent cAMP (TALAVERA; CHEW, 1987).
Besides this action on steroidogenesis, there are others beneficial effects of betacarotene on reproduction. Cows fed low betacarotene, normal vitamin A concentration, had lower pregnancy rates (COOKE; COMBDEN, 1978), delayed ovulation, greater embryo losses (WANG et al., 1988) and placental retention (MICHAL et al., 1990) compared to cows supplemented with betacarotene. Moreover, supplementation on diet with betacarotene decreased the number of services per conception in cows (SNYDER; STUART, 1981). Beside of positives effects of betacarotene, the supplementation of culture media with vitamin $\mathrm{E}$ improved in vitro mouse embryo development (WANG et al., 2002) and porcine oocyte maturation (TAO et al., 2004). Moreover, Sales et al. (2008) observed that supplementation injections of _ $\beta$-carotene associated to tocopherol improved embryo quality in superovulated Holstein cows. High betacarotene concentrations are present in the ovaries, especially in the corpus luteum (O'FALLON; CHEW, 1984; HALILOGLU et al., 2002). Thus, we postulate that in superovulated donor cows, in which there is the formation of multiple corpora lutea, the amount of betacarotene required for adequate steroidogenesis may be much greater than normal. Two experiments were conducted to evaluate the effect of the intramuscular injection of betacarotene associated to tocopherol on the plasma concentration progesterone of superovulated Holstein heifers (experiment 1) and in crossbred (Bos taurus $\mathrm{x}$ Bos indicus) heifers submitted to fixed-time embryo transfer (FTET, experiment 2). The hypothesis was: Supplemental betacarotene and vitamin E injection (injectable bolus) increases plasma progesterone concentration in heifers.

\section{MATERIALAND METHODS}

\section{Experiment 1}

\section{Animals and management}

The present experiment was conducted from October 2003 through April 2004, and treatments applied simultaneously at various time periods. Forty three reproductively sound Holstein heifers, 17 to 25 years old and with body condition scores of at least 3,0 (1-5 scale, thin to obese) (WILDMAN et al., 1982) were used. Heifers were kept on grass paddocks and supplemented daily with hay, corn silage and concentrate (soybean meal, citrus pulp, dicalcium phosphate, sodium chloride and mineral mix) to meet National Research Council - NRC (1989) requirements. 
Estrous synchronization, superovulation and artificial insemination

On Day 0 (day of implant administration), when donors were evaluated for reproductive soundness by rectal palpation, a subcutaneous ear implant was inserted with $3 \mathrm{mg}$ of norgestomet (CRESTAR ${ }^{\circledR}$, Intervert International B.V., Boxmeer, Holland), plus an i.m. injection of $3 \mathrm{mg}$ of norgestomet, and $5 \mathrm{mg}$ of estradiol valerate. On Day 5, superovulation was initiated. In the superovulation protocol 400 IU of FSH (PLUSET ${ }^{\circledR}$ I.F. Serono, Rome, Italy), were distributed in decreasing dosages of 80, 80, 60, 60, 40, 40, 20, 20 IU during 4 days, at $12 \mathrm{~h}$ intervals. Luteolysis was induced by a single i.m. injection of $500 \mu \mathrm{g}$ of DL cloprostenol (SINCROSIN ${ }^{\circledR}$, Vallée S.A., Montes Claros, Brazil) 60 hours after the administration of the first FSH dosages. The ear implants were removed on the seventh FSH injection (Day 8) and estrus was observed on Day 9. Animals in estrus were inseminated by a single experienced technician 12 and 24 $h$ after the onset of estrus. Animals were flushed on Day 16 ( 7 days after estrus).

\section{Treatments}

Heifers $(n=43)$ were allocated to treatments randomly as they entered the chute to be evaluated for reproduction soundness on Day 0 (day of ear implant insertion). The first i.m. supplementation was given on Day 0 and the second on the first day of superovulation on Day 5. Treatments were as follows: (1) $10 \mathrm{~mL}$ i.m. injection of vegetable oil (control; $n=13$ ), (2) $800 \mathrm{mg}$ of betacarotene and $500 \mathrm{mg}$ of tocopherol $(\mathrm{T} 800 ; n=17)$ and (3) $1200 \mathrm{mg}$ of betacarotene and $750 \mathrm{mg}$ of tocopherol (T1200; $n=13)$.

\section{Experiment 2}

\section{Animals}

Bos indicus $\mathrm{x}$ Bos taurus crossbred heifers $(\mathrm{n}=222)$ weighing at least $350 \mathrm{~kg}$ were used. In order to enter the experiment heifers were evaluated for reproductive soundness by rectal palpation, for regular ovarian ciclicity and for body conditioning scores higher than 3 (1- thin to 5- obese) (WILDMAN et al., 1982).

\section{Estrous synchronization for FTET}

Heifers were synchronized with a progesterone intra-vaginal device was inserted (DIB ${ }^{\circledR}$, Intervet Schering Plough, São Paulo, Brazil) on day 0 associated with $2 \mathrm{mg}$ of estradiol benzoate (RIC-BE ${ }^{\circledR}$, Syntex S.A., Argentina) injection. On day 5, 400UI eCG (Novormon ${ }^{\circledR}$, Intervet Schering Plough, Brazil) was injected followed by $150 \mu \mathrm{g}$ of cloprostenol (Prolise ${ }^{\circledR}$, ARSA S.R.L., Argentina) injection at vaginal device withdrawal, on D8. On D9, $1.0 \mathrm{mg}$ of estradiol benzoate was injected and eight days later (D17) embryos were transferred.

\section{Treatments}

Treatments were initiated imposed at intra-vaginal device insertion (D0). The same experimental as of experiment one was applied [Control $(n=72), T 800(n=72)$ e T1200 ( $\mathrm{n}=78)]$. However, only one im supplementation was given on Day 0.

\section{Blood sampling and serum progesterone analysis}

In experiment 1 , samples were collected by coccygeal vessel venopuncture from each animal on days 0, 5, 9, 12 and 16 (Figure 1). Samples at days 0 and 5 were used to determine pre-treatment progesterone concentrations. The D9 samples were used to determine progesterone concentrations at estrus $(<1.0 \mathrm{ng} / \mathrm{ml})$ (MOFFATT et al., 1993). The actual effect of betacarotene/tocopherol supplementation on serum progesterone was evaluated on samples from D12 and D16. In experiment 2, samples were collected by coccygeal vessel venopuncture on the day of the embryo transfer (D17). Samples were centrifuged $(2000 \times g)$ for $10 \mathrm{~min}$ and freezer stored in cryogenic tubes (Cryogenic vial-Corning ${ }^{\circledR}$ ) at $-21^{\circ} \mathrm{C}$. Concentrations of $\mathrm{P} 4$ in serum were analyzed using a commercial radioimmunoassay Kit (Coat-A-Count ${ }^{\circledR}$, Diagnostic Products Corporation, Los Angeles, USA). Intra-assay coefficient of variation was $2.28 \%$ and the assay sensitivity was $0.006 \mathrm{ng} / \mathrm{ml}$.

Blood samples were collected by coccygeal vessel venopuncture in 12 donors (four from each treatment) for betacarotene serum concentration determination. Samples were collected from each animal on Days 0, 5 and 16. Samples were centrifuged $(2000 \times \mathrm{g})$ for $10 \mathrm{~min}$ and freezer stored in cryogenic tubes (Cryogenic vial-Corning ${ }^{\circledR}$ ) at $-21^{\circ} \mathrm{C}$. Concentration of betacarotene was determined by high pressure liquid chromatography as previous described elsewhere (ARIKAN; RODWAY, 1997).

\section{Statistical analysis}

For statistical analysis the Statistical Analysis System for Windows SAS $^{\circledR}$ (STATISTICAL ANALYSIS SYSTEM INSTITUTE - SAS INSTITUTE, 1995) was used. The distribution of continuous variables was tested by the UNIVARIATE Barlet test which tests the variance 
homogeinity. Variables that did not meet ANOVA assumptions were transformed. Data were then submitted to PROCGLM and the means at each time point compared by the Tukey test. Responses to the synchronization protocol, conception and pregnancy rates were analyzed by the GLIMMIX. The parametric dependent variables were expressed as means and mean standard error (means \pm sem). Lest square means were calculated by the GLM procedure. Differences were considered significant when $\mathrm{P}<0.05$ and tendencies when $\mathrm{P}<0.10$.

1) Control group $(n=13)$

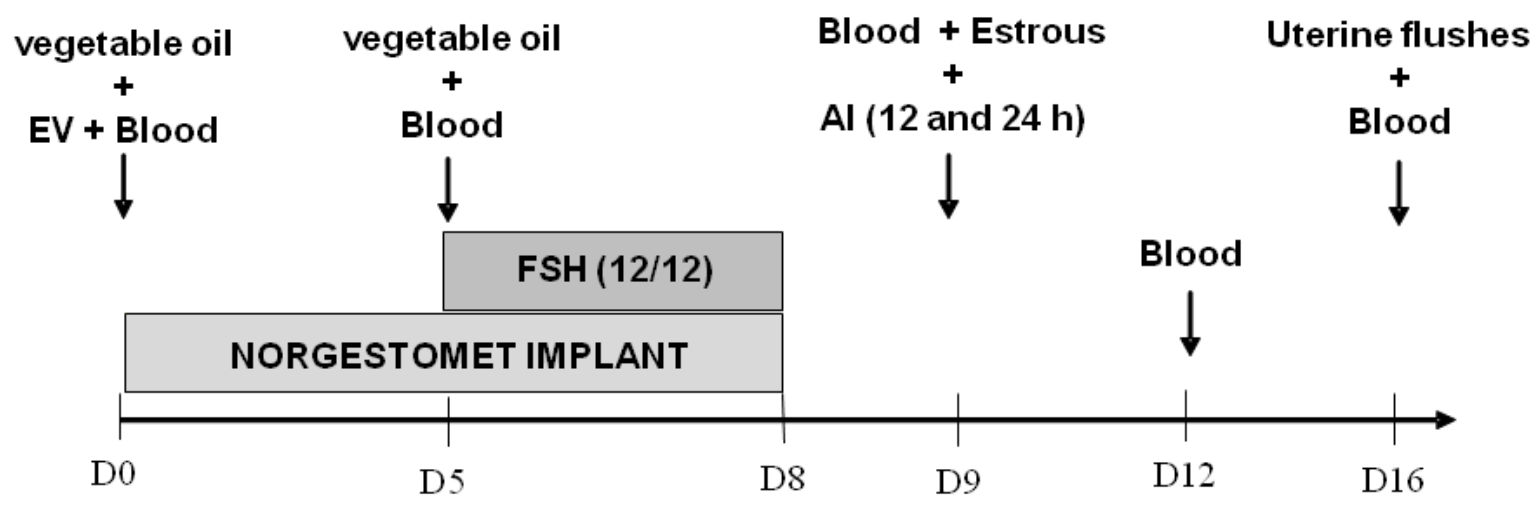

2) T800 group ( $n=17)$

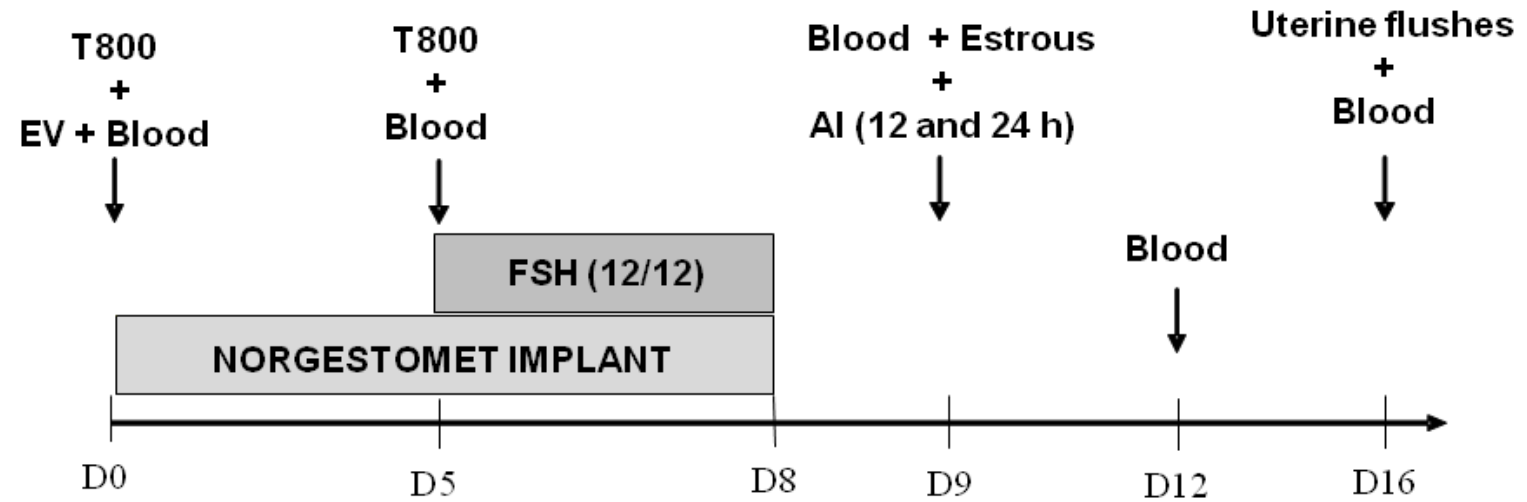

3) T1200 group (n=13)

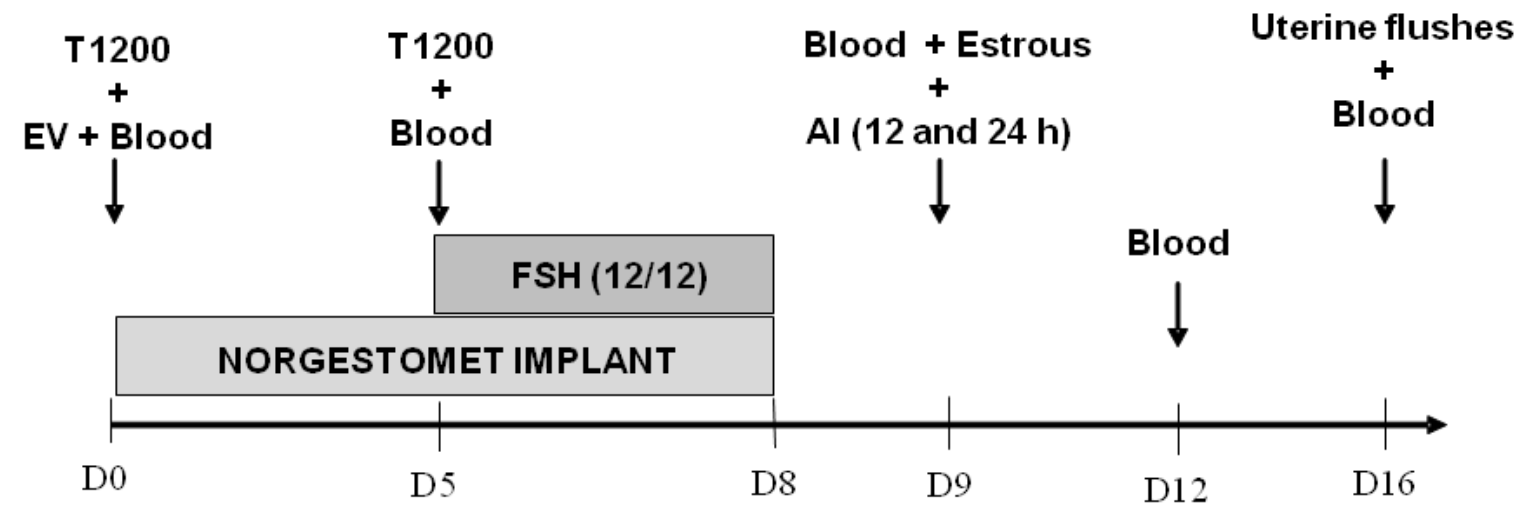

Figure 1 - Diagram of treatments and experimental activities on experiment 1. EV - Estradiol valerate. 


\section{RESULTS AND DISCUSSION}

Supplementation with $800 \mathrm{mg}$ or $1.200 \mathrm{mg}$ of betacarotene on D0 and D5 increased serum concentrations of betacarotene from $3.47 \pm 1.02$ and $5.14 \pm 1.03 \mu \mathrm{g} / \mathrm{mL}$ before treatment administration (D0) to $9.59 \pm 0.93$ and $10.89 \pm 3.35 \mu \mathrm{g} / \mathrm{mL}$ (D16), respectively (Figure 2).

Similar results were observed by Arechiga et al. (1998), in which the concentration of betacarotene, after 3 treatments, remained elevated for 19 day after injections were given. The administration i.m. of the betacarotene/ tocopherol bolus did not increase plasma progesterone in Holstein heifers donor $(\mathrm{P}=0.70)$ and recipient $(\mathrm{P}=0.13)$.

In experiment 1 , there was no interactive effect between treatments and sampling day $(\mathrm{P}>0.05)$ and mean progesterone concentrations after the formation of a corpus luteum (D12 and D16) were $13.7 \pm 1.8 \mathrm{ng} / \mathrm{mL}$ (control), $14.5 \pm 2.3 \mathrm{ng} / \mathrm{mL}(\mathrm{T} 800)$ and $10.8 \pm 2.3 \mathrm{ng} / \mathrm{mL}$ (T1200) and did not differ between treatments $(\mathrm{P}=0.44)$. In experiment 2 , progesterone concentrations on D17 in Control $(8.88 \pm 0.57 \mathrm{ng} / \mathrm{ml}), \mathrm{T} 8007.48 \pm 0.64 \mathrm{ng} / \mathrm{ml})$ and $\mathrm{T} 1200$ $(5.90 \pm 1.33 \mathrm{ng} / \mathrm{ml})$ groups were similar $(\mathrm{P}=0.11)$. Similar results were found by Wang et al. (1982) in Holstein heifers supplemented daily with $300 \mathrm{mg}$ of betacarotene for 6 to 8 weeks and by Peltier et al. (1997), in mares supplemented with $400 \mathrm{mg}$ of betacarotene by a single bolus i.m. injection and supplement of $\beta$-carotene given during the dry period in dairy cows (KAEWLAMUN et al., 2010; KAWASHIMA et al., 2010). Additionally, betacarotene did not alter progesterone concentrations of lactating dairy cows (WANG et al., 1982, 1988) and in pigs (CHEW et al., 1982; COFFEY; BRITT, 1993). This findings differ from results in other trials, in which betacarotene had a positive effect on progesterone production in vivo (WENG et al., 2000; CHEW et al., 2001) e in vitro (GRAVES-HOAGLAND et al., 1988; O'SHAUGHNESSY; WATHES, 1988; TALAVERA; CHEW, 1988; ARIKAN; RODWAY, 1997). It is possible that only locally detectable (oviduct and at the utero-oviductal junction area) increments on progesterone concentrations, not detectable in the peripheral circulation, occurred with the treatments used, theoretically, could be enough to improve embryo production. In the present study only peripheral blood samples were taken in which the dilution could mask the effect of the vitamin supplementation.

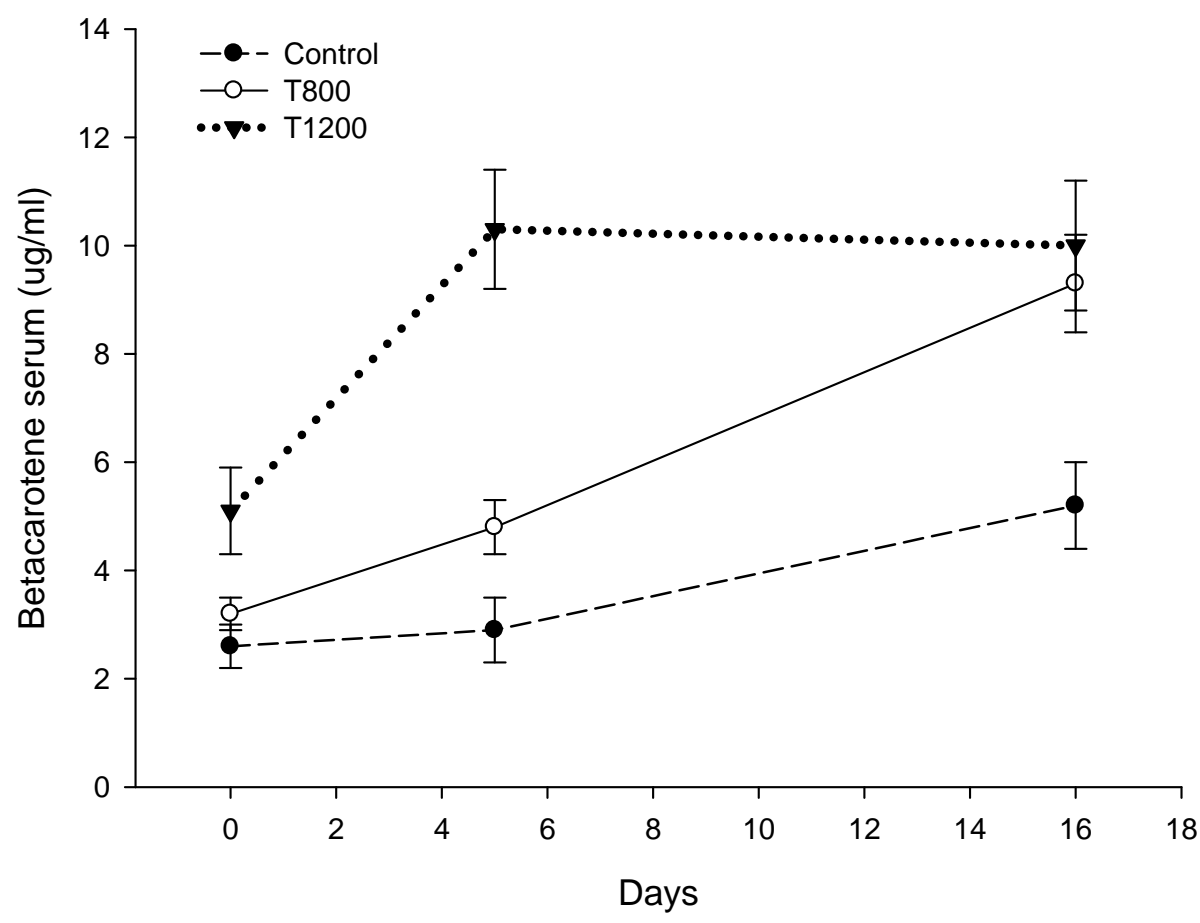

Figure 2 - Serum betacarotene concentration (determined by HPLC) in Holstein donors supplemented im with vehicle (vegetable oil-•-) 800mg (-०-) and 1,200 mg of betacarotene (- - -) on D0 and D5 of the experimental period. Arrows represent injection days. Betacarotene concentration was different $(\mathrm{P}<0.05)$ between treatments and control on D5 (*) and on D16 (**). 
The age of the heifers in the present experiment may also have played a role in the mechanism of actions of the supplementation used. It is important to consider that free radicals are critical in the maintenance of a vast array of normal physiological functions (POMPELLA, 1997) and that, according to Arechiga et al. (1998), their production may cause various degrees of infertility. In part, this decrease in fertility may be due to the fact that steroidogenic ovarian cells, spermatozoa and pre-implantation embryos are sensitive to the damage produced by oxidative agents. In addition, the activity of the antioxidant cell system and tocopherol concentrations decrease during aging, increasing ROS cell damage (RANI; PANNEERSELVAM, 2001). Therefore, since the experimental animals were young (heifers), oxidative damage may not have sufficiently compromised steroidogenesis and, consequently, progesterone production. From these observations, we may state that the supplementation of betacarotene associated to tocopherol for heifers, under these experimental conditions, is unnecessary, even under the supraphysiologic demands of ovarian superstimulation. The same may not be true for older donors.
Progesterone concentration patterns found on different sampling days were expected (Table 1). The lowest value was at D9, <1.0 ng/ml, and the greatest on D16 $(18.10 \pm 1.82 \mathrm{ng} / \mathrm{ml})$, from estrus and diestrous, respectively. Mean progesterone concentrations at D0 and D5 were $4.03 \pm 0.89 \mathrm{ng} / \mathrm{ml}$ and $1.50 \pm 0.82 \mathrm{ng} / \mathrm{ml}$ and similar to those reported by Hittinger et al. (2004). The lower progesterone concentration on D5 may be explained by the luteolytic effect of estradiol valerate injected on D0 (WILTBANK et al., 1965). The D9 blood samples, when heifers should be in estrus, should confirm the absence of a functional corpus luteum, and values should be below $1.0 \mathrm{ng} / \mathrm{ml}$ (CHRISTENSEN et al., 1974; ADEYEMO; HEALTH,1980; DÍAZ et al., 1986). Mean progesterone concentration on D9 was $0.13 \pm 0.01 \mathrm{ng} / \mathrm{ml}$ and samples from all the heifers were below $1.0 \mathrm{ng} / \mathrm{ml}$. The highest progesterone concentrations were on samples from D12 $(7.89 \pm 1.18 \mathrm{ng} / \mathrm{ml})$ and D16 $(18.10 \pm 1.82 \mathrm{ng} / \mathrm{ml})$ which were expected as a result of the multiple corpora lutea induced by superovulation (BENYEI et al., 2004). Therefore, it should not be recommended, under the present experimental conditions, as a tool to improve fertility in superovulation protocols or to heifers submitted to FTET. Whether the same recommendation would be true for cows remains to be tested.

Table 1 - Plasma progesterone concentrations (means \pm S.E.M.) in heifers supplemented with two bolus injections on experimental days 0 and 5 with vehicle (vegetable oil, $\mathrm{n}=13$ ), $800 \mathrm{mg}$ betacarotene associated to $500 \mathrm{mg}$ tocopherol (T800, $\mathrm{n}=17)$ and 1,200 mg of betacarotene associated to $750 \mathrm{mg}$ of tocopherol (T1200, $\mathrm{n}=13)$.

\begin{tabular}{ccccccc}
\hline & \multicolumn{5}{c}{ Progesterone $(\mathrm{ng} / \mathrm{ml})$} & \\
\cline { 2 - 6 } & D0 & D5 & D9 & D12 & D16 & $P$ \\
\hline Control & $3.92 \pm 0.87$ & $1.35 \pm 0.51$ & $0.13 \pm 0.05$ & $8.47 \pm 1.61$ & $18.98 \pm 2.73$ & 0.002 \\
T800 & $3.58 \pm 1.20$ & $1.59 \pm 0.49$ & $0.12 \pm 0.07$ & $7.79 \pm 1.70$ & $21.24 \pm 3.72$ & 0.001 \\
T1200 & $4.59 \pm 1.18$ & $1.56 \pm 0.62$ & $0.14 \pm 0.06$ & $7.41 \pm 2.97$ & $14.09 \pm 3.39$ & 0.002 \\
\hline
\end{tabular}

Numbers are least square means, calculated by the GLM procedure of SAS ${ }^{\oplus}$. D0 - day of progesterone implant injection; D5 - first day of superovulation; D9 - day of estrus after superovulation; D12 - three days after AI, D16 - day of embryo collection. 


\section{CONCLUSION}

Supplementation of betacarotene associated to tocopherol did not enhance peripheral progesterone concentrations in superovulated Holstein heifers and recipient crossbred heifers.

\section{ACKNOWLEDGEMENTS}

We are thankful to CAPES for the financial incentive, to Paulo Paiva and Carlos Humberto for providing the animals for embryo collection and to Vallée S.A., especially to Sergio Cirillo who provided the financial AID for the development of the project from this genuinely Brazilian company.

\section{REFERENCES}

ADEYEMO, O.; HEALTH, E. Plasma progesterone concentration in Bos taurus heifers. Theriogenology, Worburn, v.14, n.6, p.411-420, Dec. 1980.

ARECHIGA, C.G. et al. Effects of time insemination and supplemental betacarotene on reproduction and milk yield of dairy cows under heat stress.

Journal Dairy Science, Champaign, v.81, n.2, p.390402, Feb. 1998.

ARIKAN, S.; RODWAY, R.G. Effect of beta-carotene either in organic solvent or as HDL on progesterone production by bovine luteal cells. Journal of

Reproduction and Fertility, Cambridge, v.109, n.1, p.6471, Sept. 1997.

ARIKAN, S.; RODWAY, R.G. Effect of cyclodextrinencapsulated betacarotene on progesterone production by bovine luteal cells. Animal Reproduction Science, Amsterdam, v.64, n.3/4, p.149-160, Dec. 2000.

ATEN, R.F.; DUARTE, K.M.; BEHRMAN, H.R. Regulation of ovarian antioxidant vitamins, reduced glutathione, and lipid peroxidation by luteinizing hormone and prostaglandin F2 $\alpha$. Biology of Reproduction, Madison, v.46, n.3, p.401-407, Mar. 1992.

BENDICH, A.; OLSON, J.A. Biological actions of carotenoids. The FASEB Journal, Bethesda, v.3, n.8, p.1927-1932, June 1989.

BENYEI, B. et al. Progesterone profiles and oestrous cycle changes following superovulatory treatment of
Holstein-Friesian dairy cows in a tropical environment. Acta Veterinaria Hungarica, Budapeste, v.52, n.4, p.489-499, Apr. 2004.

BILSKA, A.T.G.; REDMER, D.A.; REYNOLDS, L.P. Secretion of angiogenic activity and progesterone byovine luteal cell types in vitro. Journal Animal Science, Champaign, v.69, n.5, p.2099-2107, May 1991.

BREGELIUS, F.R.; TRABER, M.G. Vitamin E: function and metabolism. The FASEB Journal, Bethesda, v.13, n.10, p.1145-1155, July 1999.

CAMPANILE, G. et al. Growth, metabolic status and ovarian function in buffalo (Bubalus bubalis) heifers fed a low energy or high energy diet. Animal Reproduction Science, Amsterdam, v.122, p.74-81, 2010.

CHEW, B.P. et al. Effects of vitamin A and betacarotene on plasma progesterone and uterine protein secretion in gilts. Theriogenology, Worburn, v.18, n.6, p.643-654, Dec. 1982.

CHEW, B.P. et al. Uptake of betacarotene by ovarian and uterine tissues and effects on steroidogenesis during the estrous cycle in cats. American Journal of Veterinary Research, Chicago, v.62, n.7, p.1063-1067, July 2001.

CHRISTENSEN, D.S.; HOPWOOD, M.L.; WILTBANK, J.N. Level of hormones in the serum of cycling beef cows. Journal of Animal Science, Champaign, v.38, n.3, p.577-583, Mar. 1974.

COFFEY, M.T.; BRITT, J.H. Enhancement of sow reproductive performance by $\mathrm{S}$-carotene or vitamin A. Journal of Animal Science, Champaign, v.71, n.5, p.1198-1202, May 1993.

COOKE, B.C.; COMBDEN, N.A. A study of the relationship between beta-carotene and fertility problems in dairy cows. Animal Production, London, v.26, n.2, p.356, Feb. 1978.

DÍAZ, T. et al. Plasma progesterone levels during the estrous cycle of Holstein and Brahman cows, Carora type and cross-bred heifers. Theriogenology, Worburn, v.26, n.4, p.419-432,Oct. 1986. 
GRAVES-HOAGLAND, R.L.; HOAGLAND, T.A.; WOODY, C.O. Effect of betacarotene and vitamin A on progesterone production by bovine luteal cells. Journal of Dairy Science, Champaign, v.71, n.4, p.1058-1062, Apr. 1988.

HALILOGLU, S. et al. Vitamin A and betacarotene levels in plasma, corpus luteum and follicular fluid of cyclic and pregnant cattle. Reproduction Domestic Animal, Oxford, v.37, n.2, p.96-99, Apr. 2002.

HITTINGER, M.A.; AMBROSE, J.D.; KASTELIC, J.P. Luteolysis, onset of estrus, and ovulation in Holstein heifers given prostaglandin $\mathrm{F}_{2 \alpha}$ concurrent with, or 24 hours prior to, removal of an intravaginal, progesteronereleasing device. Canadian Journal Veterinary Research, Ottawa, v.68, n.4, p.283-287, Mar. 2004.

JOHNSON, J.D. Do carotenoids serve as transmembrane radical channels. Free Radical Biology and Medicine, v.47, n.3, p. 321-323, 2009.

KAEWLAMUN, W. et al. Does supplementing dairy cows with $\beta$-carotene during the dry period affect postpartum ovarian activity, progesterone, and cervical and uterine involution? Theriogenology, Worburn, v.75, n.6, p.1029-1038, 2010.

KAWASHIMA, C. et al. Effect of $\beta$-carotene supply during close-up dry period on the onset of first postpartum luteal activity in dairy cows. Reproduction in Domestic Animal, Oxford, v.45, n.6, p.282-287, Dec. 2010.

LAL THANKUR, M.; SRIVASTAVA, U.S. Vitamin-E metabolism and its aplication. Nutrition Research, Cambridge, v.16, n.10, p.1767-1809, Oct. 1996.

LEROY, J.L.M.R. et al. Reduced fertility in high-yielding dairy cows: are the oocyte and embryo in danger?, part II, mechanisms linking nutrition and reduced oocyte and embryo quality in high-yielding dairy cows.

Reproduction in Domestic Animal, Oxford, v.43, n.9, p.623-632, 2008.

METRE, D.C.V.; CALLAN, R.J. Selenium and vitamin. Veterinary Clinics of North America: Food Animal Practice, Massachusetts, v.17, n.2, p.373-402, July 2001.

MICHAL, J.J. et al. Effects of supplemental betacarotene on blood and mammary phagocyte function in peripartum dairy cows. Journal of Dairy Science, Champaign, v.73, n.1, p.149, Jan. 1990. Supplement.

MOFFATT, R.J. et al. Basis of norgestomet action as a progestogen in cattle. Domestic Animal endocrinology, Auburn, v.10, n.1, p.21-30, Jan. 1993.

\section{NATIONAL RESEARCH COUNCIL. Nutrient requirements of dairy cattle. Washington, 1989.}

O'FALLON, J.V.; CHEW, B.P. The subcellular distribution of betacarotene in bovine corpus luteum. Proceeding of Society for Experimental Biology and Medice, Malden, v.177, n.3, p.406-411, Dec. 1984.

O'SHAUGHNESSY, P.J.; WATHES, D.C. Bovine luteal cell activity in culture: maintenance of steroidogenesis by high density lipoprotein containing high or low betacarotene concentrations. Animal of Reproduction Science, Amsterdam, v.17, n.3/4, p.165-176, Nov. 1988.

PELTIER, M.M. et al. Effect of betacarotene administration on reproductive function of horse and mares. Theriogenology, Worburn, v.48, n.6, p.893-906, Oct. 1997.

POMPELLA, A. Biochemistry and histochemistry of oxidant stress and lipid peroxidation. International Journal of Vitamin and Nutrition Research, Bern, v.67, n.5, p.289-297, Sept./Oct. 1997.

RANI, P.J.A.; PANNEERSELVAM, C. Carnitine as a free radical scavenger in aging. Experimental Gerontology, Oxford, v.36, n.10, p.1713-1726, Nov. 2001.

RAPOPORT, R. et al. Anti oxidant capacity is correlated with steroidogenic status of the corpus luteum during the bovine oestrous cycle.

Biochimistry Biophysis Acta, Paris, v.1380, n.1, p.133140, Mar. 1998.

SALES, J.N.S. et al. Embryo production and quality of Holstein heifers and cows supplemented with: carotene and tocopherol. Animal of Reproduction Science, Amsterdam, v.106, n.1/2, p.77-89, June 2008.

SANTOS, J.E.; CERRI, R.L.; SARTORI, R. Nutritional management of the donor cow. Theriogenology, Worburn, v.69, n.6, p.88-97, 2008. 
SIES, H.; STAHL, W. Vitamins E and C, $\beta$-carotene, and other carotenoids as antioxidants. The American Journal of Clinical Nutrition, Bethesda, v.62, n.6, p.1315S-1321S, Dec. 1995. Supplement.

SNYDER, W.E.; STUART, R.L. Nutritional role of betacarotene in bovine fertility. Journal of Dairy Science, Champaign, v.64, n.1, p.104, Jan. 1981. Supplement.

\section{STATISTICALANALYSIS SYSTEM INSTITUTE.SAS/} STAT user's guide. Version 6.12. Cary, 1995. v.2, 1686p.

TALAVERA, F.; CHEW, B.P. Comparative role of retinol, retinoic acid and betacarotene on progesterone secretion by pig corpus luteum in vitro. Journal of Reproduction and Fertility, Cambridge, v.82, n.2, p.611615, Mar. 1988.

TALAVERA, F.; CHEW, B.P. In vitro interaction of lipoproteins with retinol, retinoic acid and betacarotene on progesterone secretion by bovine luteal cells.

Journal of Dairy Science, Champaign, v.70, n.1, p.119, Jan. 1987. Supplement.

TAO, Y. et al. Exposure to L-ascorbic acid or $\alpha$ tocopherol facilitates the development of porcine denuded oocytes from metaphase i to metaphase ii and prevents cumulus cells from fragmentation.

Reproduction in Domestic Animal, Oxford, v.39, n.1, p.52-57, Feb. 2004.

WANG, J.Y.; HAFI, C.B.; LARSON, L.L. Effect of supplemental beta-carotene on luteinizing hormone released in response to gonadotropin-releasing hormone challenge in ovariectomized Holstein cows. Journal of Dairy Science, Champaign, v.71, n.2, p.489-504, Feb. 1988.

WANG, J.Y.; LARSON, L.L.; OWEN, F.G. Effect of betacarotene supplementation on reproductive performance of dairy heifers. Theriogenology, Worburn, v.18, n.4, p.461-473, Oct. 1982.

WANG, J.Y.; OWEN, F.G.; LARSON, L.L. Effect of betacarotene supplementation on reproductive performance of lactating holstein cows. Journal of Dairy Science, Champaign, v.71, n.1, p.181-186, Jan. 1988.

WANG, X. et al. Vitamin C and vitamin E supplementation reduce oxidative stress-induced embryo toxicity and improve the blastocyst development rate. Fertility and Sterility, New York, v.78, n.6, p.1272-1277, Dec. 2002.

WENG, B.C. et al. Betacarotene uptake and changes in ovarian steroids and uterine proteins during the estrous cycle in the canine. Journal of Animal Science, Champaign, v.78, n.5, p.1284-1290, May 2000.

WILDMAN, E.E. et al. A dairy cow body condition scoring system and its relationship to selected production charactristics. Journal of Dairy Science, Champaign, v.65, n.3, p.495-501, Mar. 1982.

WILTBANK, M.C.; ZIMMERMAN, D.R.; INGALLS, J.E. Use of progestational compounds alone or in combinations with estrogen for synchronization of estrus. Journal of Animal Science, Champaign, v.24, n.1, p.990-994, Nov. 1965.

WOJCIK, M.; BURZYNSKA-PEDZIWIATR, I.; WOZNIAK, L.A. A review of natural and synthetic antioxidants important for health and longevity. Current Medicinal Chemistry, v.17, n.28, p.3262-3288, 2010.

YOUNG, F.M.; LUDERER, W.B.; RODGERS, R.J. The antioxidant betacarotene prevents covalent cross-linking between cholesterol side-chain cleavage cytochrome P450 and its electron donor, adrenodoxin, in bovine luteal cells. Molecular Cellular Endocrinology, Limerick, v.109, n.1, p.113-118, Mar. 1995. 